Bangladesh J. Plant Taxon. 18(1): 51-55, 2011 (June)

(C) 2011 Bangladesh Association of Plant Taxonomists

\title{
ORNITHOGALUM BEYAZOGLUI (HYACINTHACEAE), A NEW SPECIES FROM WEST ANATOLIA, TURKEY
}

\author{
Yavuz baĞCI*, Ahmet Savran ${ }^{1}$, Olcay Dinç DÜşen ${ }^{2}$ and LÜtfi Tutar \\ Department of Biology, Faculty of Science, Selçuk University, Konya -42031, Turkey \\ Keywords: Ornithogalum beyazoglui; Hyacinthaceae; Endemic: Taxonomy; Turkey.
}

\begin{abstract}
Ornithogalum beyazoglui Y.Bağc1, Savran \& O. D. Düşen sp. nov. (Hyacinthaceae), a new species is described and illustrated from İzmir, Ödemiş, Bozdağ (İzmir, Ödemiş province). Diagnostic morphological characters are discussed, including SEM examination of seed coat surface. Data are also presented on ecology, biogeography and conservation status of the new species.
\end{abstract}

\section{Introduction}

The genus Ornithogalum L. (Hyacinthaceae) consist of about 160 species (Manning et al., 2009) and distributed in South Africa and around the Mediterranean basin, with many species of horticultural importance (Zahariad, 1980; Cullen, 1984; Heywood, 1993). Anatolia is an important distribution area for Ornithogalum in Asia.

Since Ornithogalum was revised by Cullen (1984) for the Flora of Turkey, thirty one new taxa or new records have been described from Turkey (Davis et al., 1988; Özhatay, 2000; Düşen and Sümbül, 2002, 2003; Düşen and Deniz, 2005; Uysal et al., 2005; Özhatay and Kültür, 2006; Bağc1 et al., 2009; Özhatay et al., 2009; Yıldırıml1, 2009; Koca and Y1ldirıml1, 2010). During a recent botanical expedition to Izmir in 2009, the authors collected some specimens of Ornithogalum which after critical examination were identified as new species Ornithogalum beyazoglui Y. Bağc1, Savran \& O. D. Düşen.

\section{Materials and Methods}

In May of 2009, during an expedition to the Bozdağ (Ödemiş, İzmir) in the frame of the project "A Morphological, Karyological and Molecular Phylogenetic Revision of Rorippa Scop. (Brassicaceae) species in Turkey", the authors collected some interesting Ornithogalum specimens. Further studies evidenced that they were not referable to any known taxon of the genus, and therefore a new species is here described.

A grid system was adapted for the division of the area of Turkey for the citation of specimens. This system divided Turkey into twenty-nine squares (Davis, 1965). According to this grid system, the new species growing in İzmir province falls within the A1 square.

\footnotetext{
*Corresponding author. Email: ybagci66@gmail.com

${ }^{1}$ Department of Biology, Faculty of Science and Art, Niğde University, Niğde 51100, Turkey.

${ }^{2}$ Department of Biology, Faculty of Science and Art, Pamukkale University, Denizli 20100, Turkey.
} 
For scanning electron microscope (SEM) study, the seeds were transferred directly to double-sided tape affixed stubs and sputter-coated with gold plate. Photomicrographs were taken with a Jeol JSM-5600 electron microscope at the University of Erciyes (Kayseri), Faculty of Art and Education, Deparment of Biology.

\section{Results}

Ornithogalum beyazoglui Y. Bağc1, Savran \& O. D. Düşen, sp. nov.

(Figs 1\& 2)

Type: Turkey. A1 İzmir: Ödemiş, Bozdağ, High mountain steppe, $38^{0} 19^{/} 877^{/ /} \mathrm{N}$, $28^{0} 06^{\prime} 956^{\prime \prime}$ E, 1750-1900 m, 9.6.2009, Bağc1 3936, Savran and Tutar (Holotype: KNYA, Isotypes: GAZI, PAMUH, $\mathrm{Hb}$. Y1ldırıml1 ).

Paratype: Turkey. A1 İzmir: Ödemiş, Bozdağ, High mountain steppe, damp pastureland, 1760 m, 13.5.2007, Bağc1 3604 and Savran (KNYA).

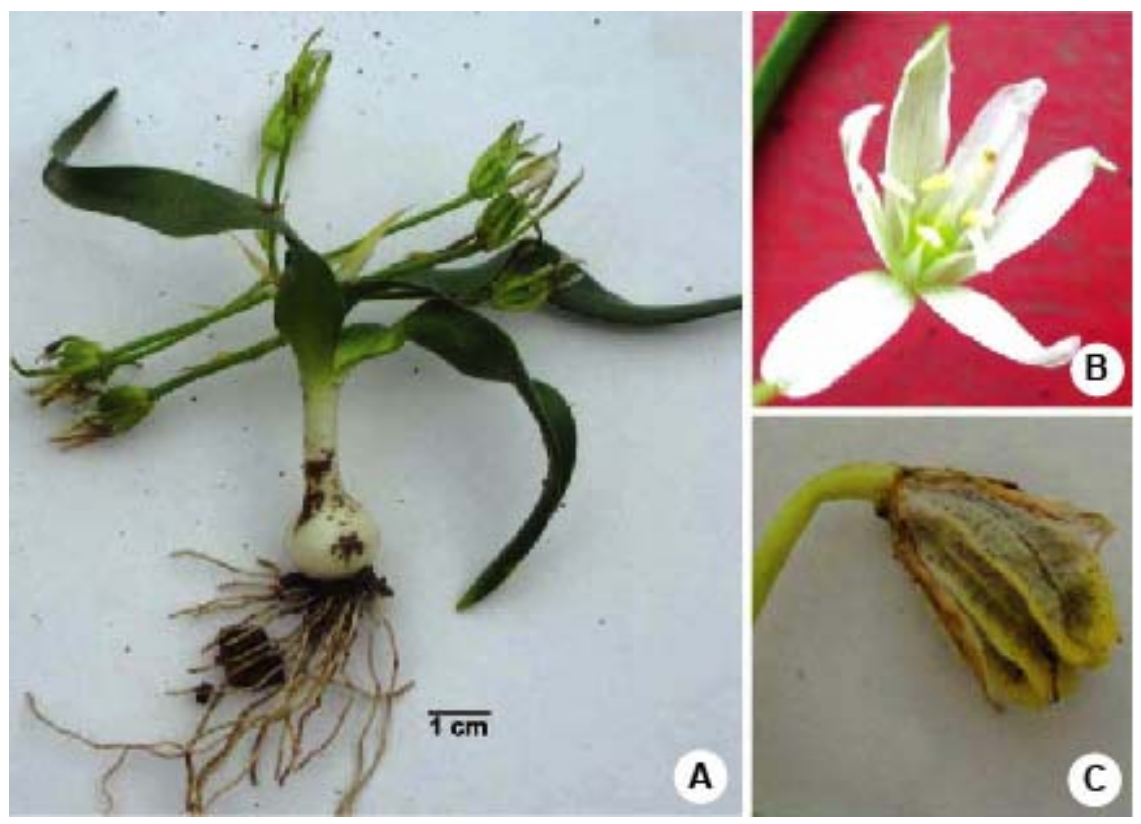

Fig. 1. Ornithogalum beyazoglui (A) Habit, (B) Flower, (C) Immature fruit.

Diagnosis: Foliaris 3-10 mm latitudo; scapis usque ad $6.5 \mathrm{~cm}$ longis; perigonio segmentis 9-12 mm longis; pedicellis fructiferis valde recurvis; filamentis $4-5 \mathrm{~mm}$ longis; capsulis alatis.

Plant 3.5-17.0 cm long. Bulb ovoid, 10-17 x 07-15 mm, without bulbils; outer tunics brown, inner whitish, membranous. Scape usually erect, 0.5-6.5 cm long, glabrous. Leaves 2-3 (-4), spreading or erect, usually lanceolate, sometimes linear-lanceolate, glabrous; 4-15 (-17) x 0.3-1.0 cm, much longer than scape, usually flat or slightly 
canaliculate, or canaliculated only at the apex, gradually tapering to acute apex, without white median line, margin entire. Raceme corymbose; 2-12 flowered, pedicels up to $3 \mathrm{~cm}$ in flower and up to $4 \mathrm{~cm}$ in fruit, ascending at anthesis but some of them strongly recurved in fruit, longer than perianth segments. Bracts 0.5-2.0 cm long, lanceolate or linear to lanceolate, acuminate, equalling or shorter than pedicels. Perianth segments 9-12 $\mathrm{mm}$ long, white inside, green with narrow white margins outside. Filaments 4-5 x 1.0-1.5 $\mathrm{mm}$, acuminate; anthers $2.0-2.5 \mathrm{~mm}$ long, whitish to dirty white, neither winged nor toothed. Ovary 2-3 x 1.5-2.0 (-3) mm wide, ovoid, longer than style; style c. 1.0-1.8 (-2) $\mathrm{mm}$ long. Capsule 0.6-1.0 x 0.5-1.0 cm, ovoid, winged. Seed numerous, black, 1.5-2.0 x 1.0-1.2 mm, rough, subglobose to globose. Flowering and fruiting time: May to June.

Etymology: This species is named in honour of the Turkish Botanist, Professor Dr. Osman Beyazoğlu (Department of Biology, Karadeniz Technical University).

Distribution and Ecology: Ornithogalum beyazoglui is a Turkish endemic species, restricted to the Bozdağ, Ödemiş-İzmir, West Anatolia, and an Irano-Turanian element. It grows on high mountain steppe and damp pastureland. Its altitudinal range is 1750-1900 $\mathrm{m}$. The new species is associated with Ornithogalum nutans, Centaurea sp., Rumex sp., and Euphorbia sp.

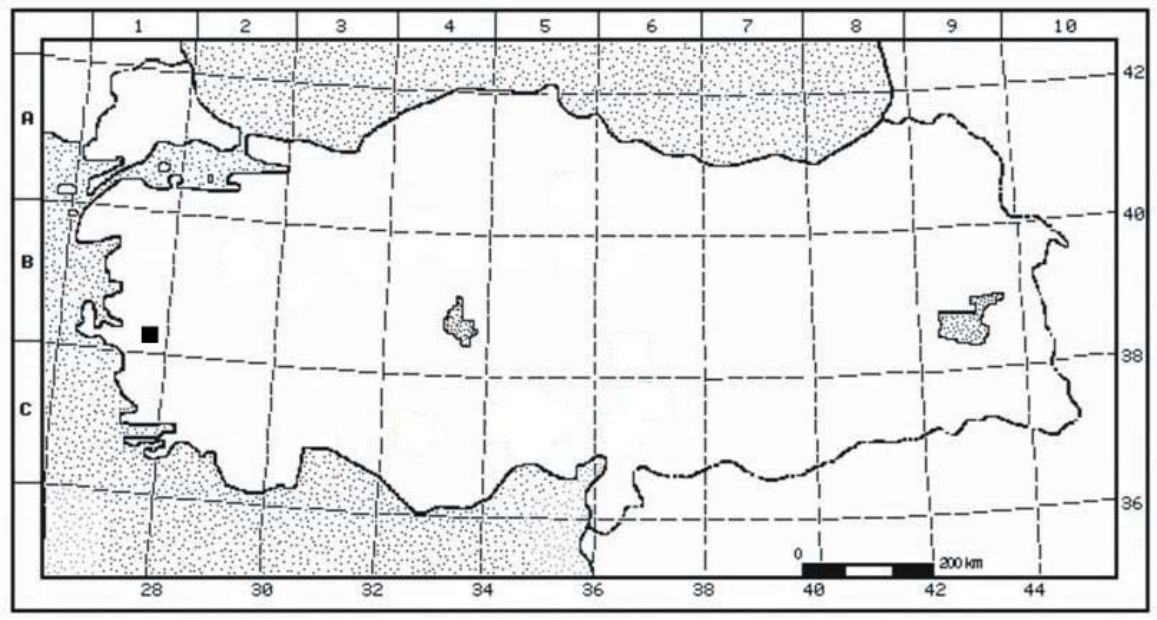

Fig. 2. Distribution map of Ornithogalum beyazoglui ( $(\mathbf{a})$

Conservational status: The specimens were collected in A1 İzmir (Ödemiş) where the species seems to be very rare and local (Fig 2). It is known only from the type locality. The range of this local endemic species is restricted to a single location (IUCN criterion B1a). The populations seem to be small and scattered on the mountain slopes where excessive grazing, erosion and human effects are threatening the species. Populations are pure, with an area of occupancy smaller than $10 \mathrm{~km}^{2}$, and according to 
field observations, it is estimated that the total number of individuals of these endemic species does not exceed 70-80 in its single locality (criteria B2a and C). Therefore we suggest that Ornithogalum beyazoglui should be labelled as Critically Endangered (CR), according to the IUCN (2001) red list categories.

\section{Seed characteristics}

In this study, the dorsal seed coat surface of Ornithogalum beyazoglui and Ornithogalum lanceolatum were examined in detail using scanning electron microscopy. Seeds of $O$. beyazoglui are blackish, subglobose to globose, 1.5-2.0 x 1.0-1.2 mm. The surface ornamentation is reticulate-rugulate. The seeds of $O$. lanceolatum are blackish, ovoid to oblong, $1.8-2.2 \times 1.8-2.0 \mathrm{~mm}$. The surface ornamentation is reticulate-striate (Fig. $3)$.
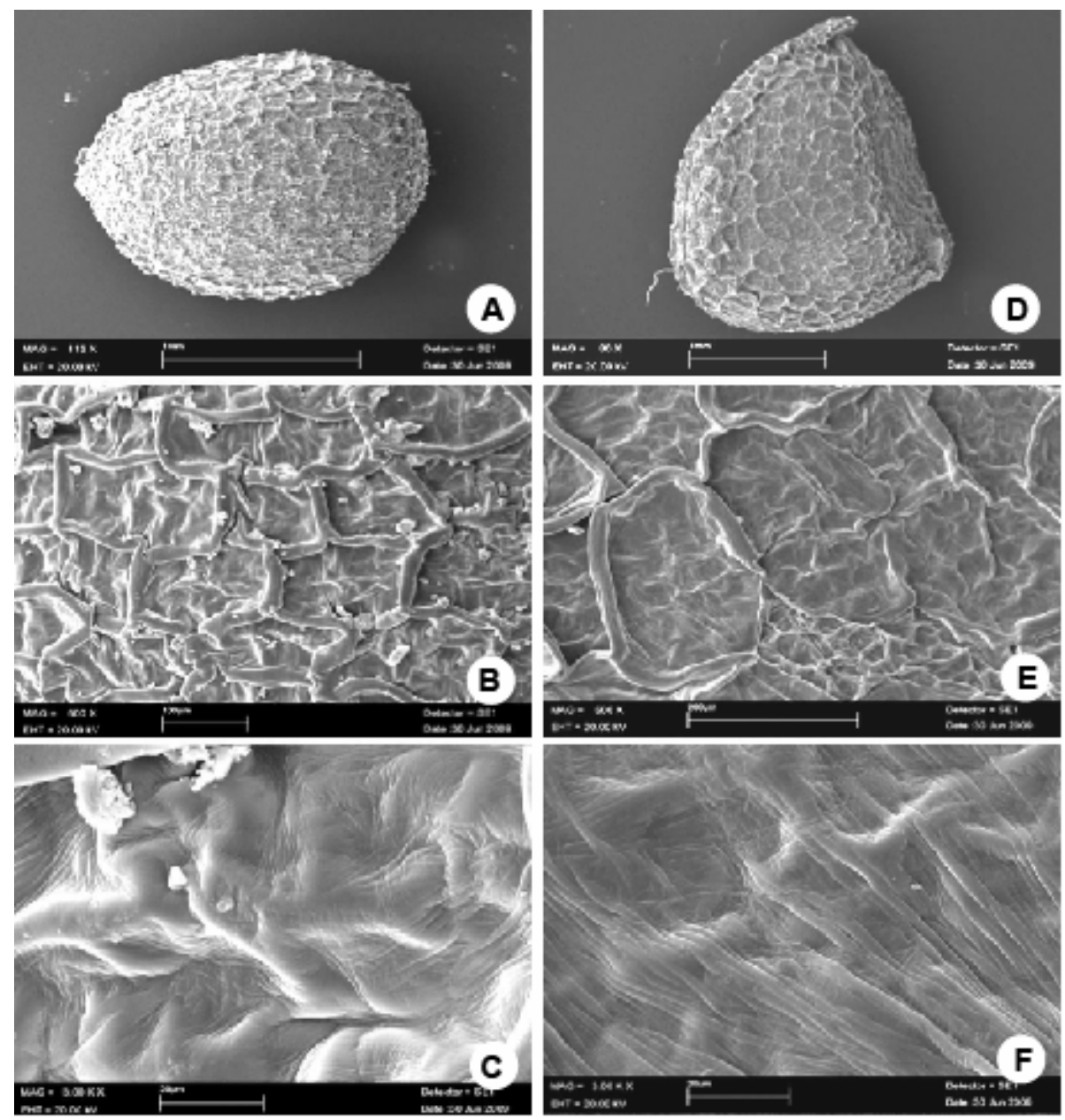

Fig. 3. SEM photographs of the seed coat. A, B \& C: Ornithogalum beyazoglui; A) General view, B \& C, Seed coat surface. D, E \& F: O. lanceolatum; D) General view, E \& F: Seed coat surface. 
The Turkish endemic Ornithogalum beyazoglui is closely related to O. lanceolatum, however, the former differs from the later by having the following characters: fruiting pedicels usually strongly recurved (not erect-spreading); leaves width 3-10 mm (not 15$20 \mathrm{~mm}$ ); filaments 4-5 $\mathrm{mm}$ long (not 6-7 $\mathrm{mm}$ ) and capsule winged (not unwinged).

\section{Acknowledgements}

The authors are indebted to Tubitak and Selçuk University Scientific Research Projects Unit for financial support. Also, we thank the Cahit Doğan for his cooperation during seed coat surface studies.

\section{References}

Bağc1, Y., Savran, A. and Başköse, İ. 2009. Ornithogalum nurdaniae (Liliaceae), a new species from NorthWest Anatolia, Turkey. Turk. J. Bot. 33: 163-167.

Cullen, J. 1984. Ornithogalum L. In: Davis, P.H. (ed.), Flora of Turkey and the East Aegean Islands. Vol. 8. Edinburgh University Press, Edinburgh, pp. 227-244.

Davis P.H. 1965. Flora of Turkey and the East Aegean Islands. Vol. 1. Edinburgh University Press, Edinburgh, pp. 1-3.

Davis, P.H., Mill, R.R. and Tan, K. 1988. Ornithogalum L. In: Davis, P.H. (ed.), Flora of Turkey and the East Aegean Islands. Vol. 10. Edinburgh University Press, Edinburgh, pp. 223-225.

Düşen, O.D. and Sümbül, H. 2002. Ornithogalum pamphylicum: New species from South Anatolia. Israel J. Plant Sci. 50: 73-76.

Düşen, O.D. and Sümbül, H. 2003. A new Ornithogalum L. species (Liliaceae) from Turkey. Israel J. Plant Sci. 51: 75-77.

Düşen, O.D. and Deniz, I.G. 2005. Ornithogalum sumbulianum (Hyacinthaceae), a new endemic species from South west Anatolia. Pak. J. Bot. 36(4): 33-36.

Heywood, V.H. 1993. Flowering plants of the world. Oxford University Press, New York, pp. 312-314.

IUCN 2001. 2001 IUCN Red List of Threatened Species. <www.iucnredlist.org>. IUCN, Gland, Switzerland.

Koca, A. and Yıldırıml1, Ş. 2010. Ornithogalum nallihanense sp. nov. (Hyacinthaceae) from northwest Anatolia, Turkey. Nord. J. Bot. 28: 329-331.

Manning, J.C., Forest, F., Devey, D.S., Fay, M.F. and Goldblatt, P. 2009. A molecular phylogeny and a revised classification of Ornithogaloideae (Hyacinthaceae) based on analysis of four plastid DNA regions. Taxon 58(1): 77-107.

Özhatay, N. 2000. Ornithogalum L. In: Güner, A., Özhatay, N., Ekim, T. and Başer, K.H.C. (eds), Flora of Turkey and the East Aegean Islands. Vol. 11. Edinburgh University Press, Edinburgh, pp. 233-237.

Özhatay, N. and Kültür, Ş. 2006. Checklist of additional taxa to the supplement flora of Turkey III. Turk. J. Bot. 30: 281-316.

Özhatay, N., Kültür, Ş. and Aslan, S. 2009. Checklist of additional taxa to the supplement flora of Turkey IV. Turk. J. Bot. 33: 191-226.

Uysal, T., Ertuğrul, K. and Dural, H. 2005. A new species of Ornithogalum (Liliaceae) from South Anatolia, Turkey. Bot. J. Linn. Soc. 148(4): 501-504.

Yıldırımlı, Ş. 2009. A new species of Ornithogalum. O. sandrasicum Yıld. (Liliaceae) from SW Anatolia, Turkey. Ot Sist. Bot. Der. 16: 1-8.

Zahariad, C. 1980. Ornithogalum L. In: Tutin, T.G., Heywood, V.H., Burges, N.A., Moore, D.M., Valentine, D.H., Walters, S.M. and Webb. D.A. (eds), Flora Europea. Vol. 5. Cambridge University Press, Cambridge, pp. 35-40. 